\title{
Reform research of Microteaching based on vocational education
}

\author{
Jia Tian \\ College of Electrical Engineering, \\ Jilin Teachers' Institute of Engineering \&Technology \\ Changchun 130052 China \\ E-mail: 158540915@QQ.COM
}

\begin{abstract}
Keywords: Micro-teaching; Vocational modern; Vocational education reform; Traditional teaching; Professional teaching approach.
\end{abstract}

\begin{abstract}
Microteaching since the introduction of the 1980s has become an effective way to train students in Normal specialty teaching skills. But with the deepening of the reform of teaching, micro-teaching in the implementation process, there have been many problems and contradictions. Especially for vocational college students, along with the modern concept of vocational education improvement and development of the community on the requirements of vocational teachers' ability and skill requirements change and other factors, resulting in micro-teaching organizational skills and formal training and employment requirements are and capacity requirements decoupling. From the Vocational Teachers Health practitioners should have the skills, ability to target should be achieved starting undergraduate, reform and innovation to explore for Microteaching Practice.
\end{abstract}

\section{Micro-teaching status quo}

In international education, micro-teaching emerged in the 1960s, attention of many national education institutions. Since the 1980s, introduced into China by the Beijing Institute of Education in the majority of the efforts of educators and popularity in our Normal Colleges are also widely carried out, become an effective way to train students in Normal teaching skills. Our existing micro-teaching skills, teaching skills to be divided into five categories: 1) instructional design skills; 2 ) the use of teaching media skills; 3) classroom teaching skills; 4)organizing and directing skills in extracurricular activities; 5)teaching and research skills. In the classroom teaching skills, he also set up nine basic skills, namely: import skills, writing on the blackboard plate painting skills, presentation skills, explain the skills, questioning skills, feedback and strengthen the skills, the end of the skills, teaching skills, organizational change skills.

After years of practice, with the deepening of the reform of teaching, learning and teaching the dominant position in the course of the exchange, the rise of a variety of teaching methods, micro-teaching stage following major problems.

Instructional design simple. Only emphasized the integrity of the teaching process, repetitive skills training, the lack of new and innovative instructional design.

The training concept obsolete. Because prior learning has been influenced by "heavy theory, light practice", so the old idea of training, focusing on teaching philosophy, teaching skills, while ignoring the practical application problems and solutions. Cause operability is not strong, timeliness is not high.

Organization and implementation of formalized processes for many years, based on the 
feedback principle and theoretical training in teaching evaluation model has been repeated, preparing lesson plans, beginning to speak, videos, self-assessment, peer assessment, teacher evaluation, re-tell. In it has been missing something, and that is to do everything standard, making the random variableof,is not standardized.

the traditional means of teaching. Teaching methods and teaching methods embodied in the form, a piece of chalk, a blackboard, within a Mandarin, the provisions of 15 minutes to complete the entire teaching. Difficult to reflect the teaching content and practice closely.

\section{The ability of normal students vocational requirements}

The Ministry of Education issued in March 2012, one of the development tasks "Decade of Education Information Development Plan" is to accelerate the construction of vocational education information, support high-quality skilled personnel training, "the quality of vocational education teachers is to promote vocational education information process one of the important factors, which requires vocational education teachers must have a good technique ability. "

Formation of educational technology ability is mainly dependent on the practice of pre-vocational training and after, and pre-service teacher education is the foundation and source of training teachers is an important way of qualified teachers in line with the requirements of the information age to breed. "Therefore, the main objective of our hospital vocational training normal students should be the development of education information services.

\section{The impact of modern vocational education concept microteaching}

Modern vocational education philosophy is based on the theory of multiple intelligences, constructivism and lifelong education theory. This requires that teachers should be based on student learning, considering the students 'ability to accept and cultivate interest in learning, and fully mobilize the students' enthusiasm and initiative, especially specialized teachers teach and teaching materials should not be constrained, but rather a new theory, new knowledge, new technology, new technology, new methods to teach students.

\section{The specific reform measures}

In order to teaching skills and future job skills match the way of thinking in order to construct lifelong learning, in order to later be able to stimulate interest in the teachers' cause all students. Demand for teachers is not only important theory, but also to re-practice; not only important knowledge, skills and abilities more training; not only pay attention to pay more attention to classroom lectures extension. Around this goal, intends microteaching following reforms to achieve better training purposes.

Speaking Lessons increase links. speakingLessons will be taught by teachers teaching content, according to the teaching ideas, teaching methods, instructional design, focusing on the design difficulty, and the key breakthrough, teaching characteristics and other objects narrated by concise language, focusing on teaching and why choose a basis to select the appropriate countermeasures. Lessons can help teachers clear thinking, better designed to teach new knowledge. Lessons vocational teachers now have links design, if not in micro-teaching undergraduate education stage, then, on the future of employment will be a big missing.

Change the traditional teaching methods. Based on action-oriented teaching discipline.In addition to classroom teachers to master the skills but also have in the laboratory, research room, and even the ability to practice the operation carried out on the production line. Based on 
action-oriented teaching ideas is to develop students' interest in learning an effective way to enhance learning ability, it is recommended to be adopted in micro-teaching professional pedagogy. Specific professional teaching there, mind maps, case teaching method, teaching method, task-driven method, brainstorming, four-phase approach, guiding text pedagogy, teaching and other technical experiments. Each training session should use the appropriate teaching methods to train for specific content.

Change the traditional lectures. Traditional lectures mostly by learning content undergraduate teaching phase, and undergraduate teaching vocational stage due to differences with the discipline system is different, our training objectives for future vocational teachers, rather than faculty, so in lectures, it should look professional in the course of this post in accordance with the duty to carry out professional directories, including the breadth and depth of the teaching objectives and so on. Another goal is to vocational training of skilled workers, so focus on practical ability, then we trained people should have the ability to train technical workers. So in the course content must select a representative, reflecting the practical ability training, and job-related content.

Change the traditional teaching situation. Traditional teaching situation in the classroom or micro classrooms throughout the session is focused on explaining the theory of knowledge, which is obviously focused on vocational training and practical ability is contrary. So we change the traditional teaching situation for work situations, based on the corresponding post group vocational professional capacity requirements, the teaching situation to work-related situations to stimulate student interest in learning, to enhance their problem-solving confidence to overcome difficulties. Driving can be selected as the laboratory site training room and even the actual production line.

To change the traditional teaching process. Previous teaching process can be divided into three parts, both imported new knowledge, new knowledge to explain, summarize. Instruction form stiff, formal organization, is not conducive to the absorption of knowledge and innovation. To adopt a student-led teaching process will greatly change this shortcoming. The entire teaching process by introducing the topic, the group discussed the issue leads, analyze problems, to design, to solve the problem, after analyzing the report, multiple evaluation and reflection test summary improve. The entire teaching process fully reflects the leading role of the student, will achieve excellent results in the future teaching actual teaching work.

\section{Conclusion}

Microteaching Training for students as a powerful tool skills, only meet the needs of the community for talent, conform to the development of modern educational philosophy of the times, in order to improve the quality of vocational teaching and training of normal students achieve better results , will lay a solid foundation for future career in vocational education.

\section{References}

[1] Yuan Nanhui, Zhang expand research into the network environment Microteaching - A Case Study of Vocational and Technical Teachers College [J] audio-visual education research, 2014,08: 78-82.

[2] Wang hua .Our teachers microteaching reform and development trend [J] Leshan Teachers College, 2010,11: 36-39.

[3] child literature, the main problem hair Cleveland, Ping Wu Yi Micro Teaching andImprovement Strategy [J] Leshan Teachers College, 2010,11: 53-54 + 57.

[4] Wang Lieqin Situation Normal University microteaching and recommendations [J] Shangluo 
University, 2008,01: 71-75.

[5] Wu Zhimin microteaching - Increases Students' Teaching Skills valid path [J] Changchun University of Technology, 2011,02: 146-147 + 152 .

[6] in the universal validity of research with new curriculum microteaching - Based on training [J] audio-visual education research, 2011,08: 113-120.

[7] Wu Yanru knowledge conversion mode and apply the policy to explore micro teaching [J] China Educational Technology, 2012,02: 109-112.Construction and Application

[8] YIN Dong microteaching digital network platform [J] China Distance Education, 2012,05: 69-75.

[9] On High Gui sensitive micro-teaching curriculum resources and teaching skills of sustainable development [J] Modern Education Science, 2012,09: 50-54.Exploring and Building

[10] Tianqiu Hua, Liu Hui cooperative interaction microteaching model [J] audio-visual education research, 2013,02: 106-110.

[11] Yan Jin. Web2.0-based micro-teaching systems research [D]. Southwestern University, 2010. 